\title{
HUBUNGAN STIMULASI ORANGTUA DENGAN PERKEMBANGAN BALITA USIA 12-36 BULAN
}

\author{
Lita Angelina Saputri ${ }^{1}$, Yefrida Rustam ${ }^{2}$, Dwi Sanella Sari ${ }^{3}$ \\ Poltekkes Kemenkes Padang ${ }^{123}$ \\ e-mail: ${ }^{1}$ litaangelinas@yahoo.com
}

\begin{abstract}
Based on data from Kemenkes RI, $48 \%$ of Indonesian children are experience developmental delays. In Padang City, the prevalence of developmental delay of children is $12 \%$ and 141 children under five years in working area Andalas Health Care experience developmental delay. One of factors causing developmental delay is the failure or delay in giving stimulation. The objective of this study was to determine the relationship between parent stimulation and the development of toddler aged 12-36 months in Andalas Village, working area Andalas Health Care City of Padang. This type of research is descriptive analytic with cross sectional approach. Data were collected in Andalas Village working area Andalas Health Care at August 2017-May 2018. The population of this research are all parents who have toddler aged 12-36 months in Andalas Village with 40 respondents using multistage random samplin technique. Data were collected by filling questionnaire The Infant/Toddler Home Observation for Measurement of The Environment (HOME) and KPSP. The data analysis consisted of univariate and bivariate analysis using Chisquare test with confident interval 95\%. The result showed 23 respondents (57,5\%) with parent's good stimulation and 24 respondents $(60 \%)$ have appropriate developments. Results of bivariate analysis $p$ value $=0.000$, meaning that there is a significant relationship between parent's stimulation and the development of children aged 12-36 months.Based on the analysis we can conclude that there is a relationship between parent stimulation and the development of toddler aged 12-36 months. It is expected that health workers to provide information for parents about developmental stimulation and perform early detection of children development optimally.
\end{abstract}

Keywords: Parent Stimulation;Development;Toddler

\begin{abstract}
ABSTRAK
Berdasarkan data dari Kemenkes RI terdapat $48 \%$ anak Indonesia yang mengalami keterlambatan perkembangan. Di Kota Padang, prevalensi gangguan perkembangan anak sebesar $12 \%$ dan didapatkan 141 balita di wilayah kerja Puskesmas Andalas mengalami gangguan perkembangan. Salah satu faktor penyebabketerlambatan perkembangan adalah kesalahan atau keterlambatan memberikan stimulasi. Tujuan penelitian ini untuk mengetahui hubungan stimulasi orangtua dengan perkembangan balita usia 12-36 bulan di Kelurahan Andalas wilayah kerja Puskesmas Andalas Padang. Jenispenelitian survei analitik dengan pendekatan cross sectional. Penelitian dilakukan di Kelurahan Andalaswilayah kerja Puskesmas Andalaspada Agustus 2017-Mei 2018. Populasi adalah seluruh orangtua yang memiliki balita usia 12-36 bulan dan sampel diambil menggunakan teknik multistage random sampling dengan jumlah 40 responden. Pengumpulan data dengan KPSP dan kuesioner untuk menilai stimulasi orangtua pada balita yang sudah baku. Analisis data terdiri dari univariat dan bivariat dengan uji Chi-squaredengan derajat kepercayaan 95\%.Hasilpenelitian didapatkan sebanyak 23 responden $(57,5 \%)$ dengan stimulasi baik dan 24 responden $(60 \%)$ dengan perkembangan yang sesuai. Hasil sanalisa bivariat didapatkan adanya hubungan antara stimulasi orangua dengan perkembangan balita usia 12-36 bulan dengan p-value $=0,000$. Dapat disimpulkan ada hubungan stimulasi orangtua dengan perkembangan balita usia 12-36 bulan. Diharapkan petugas kesehatan memberikan informasi kepada orangtua terkait stimulasi perkembangan dan melakukan deteksi dini perkembangan secara optimal.
\end{abstract}

Kata Kunci: Stimulasi orang tua; perkembangan; balita 


\section{PENDAHULUAN}

Pembangunan kesehatan sebagai bagian dari upaya membangun manusia seutuhnya antara lain diselenggarakan melalui upaya kesehatan anak yang dilakukan sejak anak masih di dalam kandungan sampai lima tahun pertama kehidupannya. Pada usia ini, anak harus mendapat perhatian yang serius, selain gizi yang baik, stimulasi yang memadai, juga faktor-faktor yang dapat mengganggu perkembangan anak harus di eliminasi. ${ }^{(1),(2)}$

Pada usia di bawah tiga tahun, pertumbuhan otak telah mencapai $80 \%$ ukuran otak dewasa dengan jumlah sinaps dua kali lipat dibanding otak orang dewasa sehingga periode ini merupakan periode kritis untuk perkembangan anak. Apabila pada masa tersebut anak balita tidak dibina secara baik, maka anak tersebut akan mengalami gangguan perkembangan baik emosi, sosial, mental, intelektual dan moral yang akan sangat menentukan sikap serta nilai pola perilaku seseorang dikemudian hari. ${ }^{(2)}$

Lebih dari dua dekade diketahui masalah perkembangan merupakan "new morbidity". Diperkirakan bahwa 200 juta anak di bawah usia lima tahun di negara berkembang mengalami gangguan perkembangan karena kemiskinan, malnutrisi, tingkat infeksi yang tinggi, kurangnya stimulasi dan edukasi serta ketidakstabilan di rumah. Angka kejadian penyimpangan perkembangan pada anak di seluruh dunia adalah 10-17\%. Angka kejadian keterlambatan perkembangan di Amerika 12-16\%, Argentina $20 \%$, Thailand $37,1 \%$ dan Indonesia $13-18 \%$. (3)

Sebanyak 0,25\% anak usia 12-36 bulan di Asia mengalami penyimpangan perkembangan dan $5 \%$ diantaranya berada di Indonesia. Data dari Depkes RI tahun 2010 menunjukkan $48 \%$ anak Indonesia mengalamiketerlambatan perkembangan dan $23 \%$ diantaranya terjadi karena kesalahan atau keterlambatan dalam memberikan stimulasi. $^{(3),(4)}$

Data dari IDAI tahun 2013 didapatkan angka kejadian keterlambatan perkembangan umum terjadi sekitar 1-3\% pada anak di bawah usia 5 tahun. Berdasarkan penelitian retrospektif yang dilakukan di RSAB Harapan Kita Jakarta didapatkan 30,9\% anak di bawah lima tahun mengalami keterlambatan perkembangan umum. Keluhan terbanyak berupa gangguan bicara $(46,8 \%)$ dan perkembangan gerak terlambat $(30,9 \%) .{ }^{(4)}$

Perkembangan (development) adalah bertambahnya struktur dan fungsi tubuh yang lebih kompleks dalam kemampuan gerak kasar, gerak halus, bicara dan bahasa serta sosialisasi dan kemandirian. Perkembangan anak merupakan proses kontinu yang terjadi mulai sejak konsepsi sampai dewasa. Perkembangan anak dipengaruhi oleh faktor genetik dan faktor lingkungan. Agar faktor lingkungan memberikan pengaruh yang positif bagi perkembangan anak, maka diperlukan pemenuhan atas kebutuhan dasar tertentu salah satunya kebutuhan asuh (kebutuhan fisik-biomedis, seperti nutrisi yang seimbang), kebutuhan asih (pemberian moral/kasih sayang) dan kebutuhan asah (pemberian stimulasi). ${ }^{(5),(6)}$

Perkembangan anak berjalan sesuai dengan potensi genetiknya tergantung pada lingkungan di sekitar anak dalam memanfaatkan masa kritis. Salah satu faktor lingkungan yang dapat mengoptimalkan perkembangan adalah stimulasi. Stimulasiadalah perangsangan (penglihatan, bicara, pendengaran, perabaan) yang datang dari lingkungan anak. Pemberian stimulasi akan efektif apabila dilakukan pada periode kritis (golden age period).Stimulasi sebaiknya dilakukan terhadap semua aspek perkembangan anak secara proposional, baik dalam kualitas maupun kuantitas, dan sesuai dengan tingkat maturitas saraf anak. Kurangnya stimulasi dan kualitas pengasuhan pada golden age period akan menghambat perkembangan emosional, sosial, fisik dan kognitif mereka. ${ }^{(2)}$

Stimulasi harus dilakukan sedini mungkin, bahkan sejak anak masih di dalam kandungan. Stimulasi diberikan dengan melibatkan semua anggota keluarga, selain itu juga oleh petugas kesehatan saat merawat anak. Stimulasi mempunyai arti yang besar terhadap perkembangan anak. ${ }^{(7)}$ Anak yang banyak mendapatkan stimulasi akan lebih cepat berkembang daripada anak yang kurang atau bahkan tidak mendapatkan stimulasi. Anak dengan stimulasi yang memadai memiliki fungsi otak yang lebih baik yang terukur saat usia 12 tahun dibanding dengan anak yang kurang mendapatkan stimulasi. Dengan pemberian stimulasi, diharapkan pada waktu dewasa kelak selain mempunyai kecerdasan intelektual (IQ) anak juga mempunyai kecerdasan emosional (EQ) dan kecerdasan moralspiritual (SQ) yang tinggi. ${ }^{(2),(8)}$

Keluarga merupakan lingkungan awal dan utama berperan dalam perkembangan anak. Kemampuan anak dalam keluarga di stimulasi oleh ibu, ayah, anggota keluarga lain serta lingkungan di sekitar anak tersebut. Penelitian tentang peran stimulasi orangtua terhadap perkembangan balita pada keluarga miskin yang dilakukan di Bogor didapatkan bahwa stimulasi terhadap perkembangan anak hanya dilakukan oleh $48-72 \%$ keluarga. ${ }^{(9),(10)}$ 
Stimulasi orangtua yang kurang merupakan faktor risiko disfasi perkembangan pada anak usia 12-36 bulan. Penelitian tentang stimulasi dini pada pola asuh berdampak positif terhadap perkembangan baduta di Jakarta didapatkan hasil bahwa anak di bawahdua tahun yang pemenuhan stimulasinya terpenuhi memiliki peluang 7,3 kali mencapai perkembangan sesuai daripada anak yang tidak mendapatkan stimulasi. Menurut penelitian lain tentang pengaruh pemberian stimulasi pada perkembangan anak usia 12-36 bulan di Bantul didapatkan hasil batita yang diberi stimulasi $85,7 \%$ memiliki perkembangan yang sesuai dibanding yang tidak diberi stimulasi $68,6 \%$ memiliki perkembangan yang tidak sesuai. ${ }^{(9),(11)}$

Penelitian tentang efek kurangnya stimulasi pada anak di Eropa didapatkan $70 \%$ anak balita mengalami gangguan perkembangan bahasa dan mengalami kesulitan dalam bersosialisasi. Penelitian lain juga memperlihatkan kurangnya stimulasi dapat mempengaruhi perkembangan kognitif, bahasa dan sosial dan $15 \%$ anak antara usia 2-9 tahun mengalami kesulitan dalam belajar dan berpikir. $\left({ }^{12)}\right.$

Berdasarkan masalah perkembangan anak diatas maka pemerintah telah melakukan berbagai upaya dalam mendukung pelaksanaan Stimulasi Deteksi dan Intervensi Dini Tumbuh Kembang (SDIDTK) dan membuat metode deteksi dini untuk mengetahui penyimpangan perkembangan anak dan skrining untuk mengetahui penyakit potensial yang dapat mengakibatkan penyimpangan perkembangan anak dengan KPSP. Penelitian tentang analisis program SDIDTK di Semarang memperlihatkan bahwa pelaksanaan Program Stimulasi, Deteksi, dan Intervensi Dini Tumbuh Kembang (SDIDTK) balita masih terbatas pada deteksi dini penyimpangan pertumbuhan sedangkan deteksi dini penyimpangan perkembangan, penyimpangan emosional, dan stimulasi sesuai usia anak belum dilaksanakan. ${ }^{(13)}$

Banyak yang percaya bahwa tidak banyak yang dilakukan untuk mengatasi masalah penyimpangan perkembangan dan mereka percaya bahwa penyimpangan yang ringan dapat menjadi normal dengan sendirinya. Sikap seperti ini pada kasuskasus tertentu dapat mengakibatkan cacat yang permanen. ${ }^{(14)}$ Prevalensi anak dengan gangguan perkembangan di Kota Padang sebesar $12 \%$ dari 53.263 balita di tahun 2013. Berdasarkan data dari Dinas Kesehatan Kota Padang tahun 2016, cakupan DDTK kontak I pada anak balita Kota Padang tidak mencapai target $(90 \%)$ dan rata-rata cakupan DDTK kontak I pada anak balita Kota Padang sebesar 72,7\%. Puskesmas Andalas adalah salah satu puskesmas yang tidak mencapai target cakupan DDTK kontak I anak balita dan berada di bawah cakupan rata-rata Kota Padang yakni sebesar 68,5\%. Wilayah kerja Puskesmas Andalas juga merupakan puskesmas yang memiliki balita terbanyak dengan jumlah 5956 orang. ${ }^{(15),(16)}$

Berdasarkan data dari laporan tahunan Puskesmas Andalas tahun 2016 didapatkan 141 orang balita di wilayah kerja Puskesmas Andalas yang perkembangannya tidak sesuai dengan yang seharusnya. Wilayah kerja Puskesmas Andalas terdiri dari 10 kelurahan salah satunya adalah Kelurahan Andalas. Kelurahan Andalas juga merupakan salah satu kelurahan yang cakupan DDTK rendah yaitu $86,5 \%$ dengan jumlah balita usia 12-36 bulan terbanyak yaitu 405 orang.

Berdasarkan studi pendahuluan yang dilakukan peneliti di Kelurahan Andalas dari 10 orangtua yang memiliki balita usia 12-36 bulan yang dilakukan melalui wawancara tentang pemberian stimulasi didapatkan 4 orangtua sering memberikan stimulasi dalam bentuk mengajak anak menggambar, melihat buku, melempar dan menangkap bola, mengajarkan anak makan dengan sendok, serta bermain petak umpet sedangkan 6 lainnya jarang memberikan stimulasi tersebut.Empat orangtua yang sering memberikan stimulasi dan dua orangtua yang jarang memberikan stimulasi memiliki anak yang perkembangannya sesuai dan empat orangtualain yang juga jarang memberikan stimulasi memiliki anak yang perkembangannya meragukan, dimana terdapat satu anak yang belum bisa berjalan dan tiga lainnya belum bisa bicara 2-3 suku kata.Berdasarkan fenomena di atas peneliti tertarik untuk melakukan penelitian mengenai hubungan stimulasi orangtua dengan perkembangan balita usia 12-36 bulan.

\section{METODE}

Penelitian ini menggunakan jenis survei analitik dengan pendekatan cross sectional. Lokasi penelitian dilakukan di Kelurahan Andalas wilayah kerja Puskesmas Andalas Padang. Pelaksanaan penelitian dilakukan pada Agustus 2017-Mei 2018. Populasi dari penelitian ini adalah seluruh orangtua yang memiliki balita usia 12-36 bulan di Kelurahan Andalas, Kota Padang dengan Sampel sebanyak 40 responden, diambil menggunakan teknik multistage random sampling yang memenuhi kriteria yaitu pengasuh utama adalah salah satu orangtua yang bisa membaca dan menulis, saat pemeriksaan balita dalam keadaan sehat, tidak memiliki riwayat lahir 
prematur, tidak memiliki kelainan bawaan atau cacat tubuh, ibu dan balita bersedia menjadi responden. Pengambilan data dilakukan dengan cara wawancara dan observasi dengan menggunakan instrumen untuk pengumpulan data yaitu : kuisioner The Infant/Toddler HOME untuk mengukur kualitas stimulasi orangtua dan KPSP untuk menilai perkembangan balita. Analisis data menggunakan komputer dan diolah menggunakan SPSS, terdiri dari : Analisis Univariat dan Bivariat dengan uji Chi-square. Variabel bebas dalam penelitian ini adalah stimulasi orangtua dan variabel terikat adalah perkembangan balita usia 12-36 bulan.

\section{HASIL}

\section{Analisis Univariat}

Tabel 1. Distribusi Frekuensi Perkembangan Balita Usia 12-36 Bulan

\begin{tabular}{llll} 
& B Perkembangan Balita & f & \% \\
\cline { 2 - 4 } erda & Penyimpangan & 4 & 10 \\
\cline { 2 - 4 } sark & Meragukan & 12 & 30 \\
\cline { 2 - 4 } an & Sesuai & 24 & 60 \\
\cline { 2 - 4 } 1 & \multicolumn{1}{c}{ Jumlah } & 40 & 100 \\
\cline { 2 - 4 } & &
\end{tabular}

dapa

$\mathrm{t}$ dilihat bahwa perkembangan balita paling banyak berada pada kategori sesuai yaitu sebanyak 24 responden $(60 \%)$.

Tabel 2. Distribusi Frekuensi Stimulasi Orangtua

\begin{tabular}{|c|c|c|c|c|c|c|c|}
\hline \multicolumn{5}{|c|}{ Stimulasi Orang Tua } & $\mathbf{f}$ & \multicolumn{2}{|c|}{$\%$} \\
\hline \multicolumn{5}{|c|}{ Kurang } & 3 & \multicolumn{2}{|c|}{7,5} \\
\hline \multicolumn{5}{|c|}{ Sedang } & 14 & \multicolumn{2}{|c|}{35} \\
\hline \multicolumn{2}{|l|}{ Baik } & & & & 23 & \multicolumn{2}{|c|}{57,5} \\
\hline \multirow{3}{*}{$\begin{array}{c}\text { Stimulas } \\
\text { i } \\
\text { Orangtu } \\
\mathbf{a}\end{array}$} & \multicolumn{4}{|c|}{$\begin{array}{c}\text { Perkembangan } \\
\text { Balita }\end{array}$} & \multirow{2}{*}{\multicolumn{2}{|c|}{$\begin{array}{c}\text { Jumla } \\
\mathbf{h}\end{array}$}} & \multirow{3}{*}{$\begin{array}{c}P \\
\text { valu } \\
e\end{array}$} \\
\hline & \multicolumn{2}{|c|}{$\begin{array}{c}\text { Tidak } \\
\text { Sesuai } \\
\end{array}$} & \multicolumn{2}{|c|}{ Sesuai } & & & \\
\hline & $\mathbf{f}$ & $\%$ & $\mathbf{f}$ & $\%$ & $\mathbf{f}$ & $\%$ & \\
\hline $\begin{array}{l}\text { Kurang } \\
\text { - } \\
\text { Sedang }\end{array}$ & 14 & $\begin{array}{c}82 \\
4\end{array}$ & 3 & 17,6 & $\begin{array}{l}1 \\
7\end{array}$ & 100 & 0,00 \\
\hline Baik & 2 & 8,7 & 21 & 91,3 & 23 & 100 & 0 \\
\hline Jumlah & 16 & & 24 & & & & \\
\hline
\end{tabular}

\begin{tabular}{ccc}
\hline Jumlah & 40 & 100 \\
\hline
\end{tabular}

Berdasarkan tabel 2 dapat diketahui bahwa pemberian stimulasi oleh orangtua paling banyak berada dalam kategori baik yaitu sebanyak 23 orang $(57,5 \%)$.

\section{Analisis Bivariat}

Tabel 3. Hubungan Stimulasi Orangtua dengan Perkembangan Balita Usia 12-36 Bulan

Berdasarkan tabel 3 dapat dilihat bahwa dari 17 responden yang mendapatkan stimulasi kurangsedang, 82,4\% diantaranya memiliki perkembangan tidak sesuai dengan usianya, sedangkan dari 23 responden yang mendapatkan stimulasi baik, 8,7\% diantaranya memiliki perkembangan tidak sesuai. Setelah dilakukan uji statistik dengan menggunakan uji chi-square dengan derajat kepercayaan 95\% didapatkan $\mathrm{p}$ value $=0,000$, nilai ini kecil dari $\alpha$ yaitu 0,05 . Hal ini Ho ditolak sehingga terdapat hubungan yang bermakna antara stimulasi orangtua dengan perkembangan balita usia 12-36 bulan.

\section{PEMBAHASAN}

Hasil penelitian menunjukkan sebagian besar responden memiliki perkembangan yang sesuai dengan tahap perkembangan usianya (60\%). Hasil penelitian ini sejalan dengan penelitian yang dilakukan oleh Asih di Lampung Tengah tahun 2011 dimana sebanyak $81,7 \%$ responden memiliki perkembangan yang sesuai. ${ }^{(17)}$

Perkembangan (development) adalah perubahan yang bersifat kuantitatif dan kualitatif berkaitan dengan pematangan fungsi organ/individu yang memiliki pola teratur, dapat diramalkan, dan merupakan proses dari maturitas susunan saraf pusat dan belajar serta dimulai dari yang sederhana hingga kompleks dalam kemampuan gerak kasar, gerak halus, bicara dan bahasa serta sosialisasi dan kemandirian. ${ }^{(1)}$

Perkembangan balita yang sesuai didukung oleh faktor biologis dan psikososial. Lingkungan merupakan faktor yang sangat menentukan tercapai atau tidaknya perkembangan. Lingkungan yang baik akan memungkinkan tercapainya perkembangan yang optimal, sedangkan lingkungan yang kurang baik akan menghambat perkembangan diantaranya sanitasi lingkungan.

Perkembangan anak dapat dilihat dari kualitas interaksi anak dan orangtua. Interaksi timbal balik antara anak dan orangtua akan menimbulkan 
keakraban dalam keluarga. Interaksi tidak ditentukan oleh seberapa lama bersama anak tetapi lebih ditentukan oleh kualitas dari interaksi tersebut yaitu pemahaman terhadap kebutuhan masingmasing dan upaya optimal untuk memenuhi kebutuhan tersebut yang dilandasi dengan rasa cinta dan kasih sayang. ${ }^{(2)}$

Penilaian perkembangan dilakukan dengan KPSP (Kuesioner Pra Skrinning Perkembangan) yang terdiri dari 10 pertanyaan sesuai usia balita.Apabila ditinjau dari kelompok anak yang memiliki perkembangan tidak sesuai maka semua aspek perkembangan mengalami gangguan, yang terbanyak adalah gangguan motorik kasar sebanyak 12 kasus (30\%), diikuti gangguan bicara dan bahasa sebanyak 8 kasus (20\%), sosialisasi dan kemandirian sebanyak 7 kasus $(17,5 \%)$ dan motorik halus sebanyak 5 kasus $(12,5 \%)$.

Hal ini sesuai dengan penelitian Gunawan, dkk yang dilakukan di Bandung tahun 2010. Hasil penelitian mendapatkan gangguan terbanyak adalah motorik kasar $(6,17 \%)$ diikuti dengan gangguan bicara dan bahasa $(4,54 \%)$. Sedangkan penelitian lain yang dilakukan Humaira,dkk di Padang tahun 2014 mendapatkan aspek gangguan perkembangan terbanyak adalah motorik kasar $(33,3 \%)$ diikuti gangguan motorik halus $(31,4 \%)$. Penelitian Souza, dkk di Brazil tahun 2010 mendapatkan 30\% anak mengalami keterlambatan perkembangan motorik kasar dan motorik halus pada subjek berusia 12-17 bulan. ${ }^{(18)}$

Hasil penelitian menunjukkan masih banyak balita dengan perkembangan yang tidak sesuai dengan umurnya. Oleh sebab itu, karena masa tiga tahun pertama kehidupan merupakan masa yang paling penting dalam perkembangan anak (golden period) perlu ditingkatkan peran dan kesadaran orangtua dalam memperhatikan fase perkembangan anak yang sesuai dengan usianya dan memberikan stimulasi beragam yang dibutuhkan oleh anak untuk mencapai perkembangan optimal.

Berdasarkan hasil penelitian juga diketahui bahwa lebih dari separuh responden memberikan stimulasi yang baik kepada balita $(57,5 \%)$. Hasil penelitian ini sejalan dengan penilitian yang dilakukan oleh Kusumanegara, dkk yang juga mendapatkan sebagian besar orangtua memberikan stimulasi dengan baik $(76,9 \%)$.

Stimulasi orangtua merupakan bagian dari kebutuhan dasar anak yaitu asah. Stimulasi orangtua adalah kegiatan merangsang kemampuan dasar anak oleh orangtua agar anak dapat tumbuh dan berkembang secara optimal. Setiap anak perlu mendapat stimulasi sedini mungkin dan terus menerus oleh ibu dan ayah yang merupakan orang terdekat anak, anggota keluarga lain dan kelompok masyarakat di lingkungan rumah tangga masingmasing dan dalam kehidupan sehari-hari. ${ }^{(2)}$

Penilaian stimulasi orangtua dilakukan dengan alat bantu The Infant/ Toddler HOME yang dikembangkan oleh Caldwell dan Bradley dimana stimulasi orangtua terhadap balita usia 12-36 bulan akan dilihat dari 6 aspek yaitu tanggap rasa dan kata, penerimaan terhadap perilaku anak, pengorganisasian lingkungan anak, stimulasi belajar, keterlibatan orangtua dan variasi asuhan. ${ }^{(34)}$ Berdasarkan wawancara dan observasi yang dilakukan oleh peneliti terhadap responden paling banyak orangtua memberikan stimulasi dalam subkala keterlibatan orangtua $(85 \%)$, subskala penerimaan perilaku anak $(57,5 \%)$, subkala tanggap rasa dan kata $(55 \%)$, stimulasi belajar $(42,5 \%)$, variasi asuhan (30\%), dan paling sedikit memberikan stimulasi dalam subskala pengorganisasian lingkungan $(5 \%)$.

Setelah dilakukan uji statistik menggunakan chisquare dengan derajat kepercayaan $95 \%$ didapatkan p value $=0,000$, nilai ini kecil dari $\alpha$ yaitu 0,05 . Hal ini berarti terdapat hubungan bermakna antara stimulasi orangtua dengan perkembangan balita usia 12-36 bulan.

Hasil penelitian ini sejalan dengan hasil penelitian yang dilakukan oleh Kusumanegara,dkk di Semarang tahun 2015 yang mendapatkan hasil adanya hubungan antara stimulasi keluarga dengan perkembangan batita (pvalue $=0,001)$. Penelitian ini mendapatkan dari 84 responden didapatkan 15 responden $(17,86 \%)$ suspek gangguan perkembangan dengan 12 responden $(86,7 \%)$ suspek gangguan perkembangan mendapatkan stimulasi keluarga kurang. ${ }^{(18)}$

Penelitian lain yang dilakukan oleh Wulandari di Yogyakarta tahun 2017 juga menemukan ada hubungan antara stimulasi orangtua dengan perkembangan anak ( $\mathrm{p}$ value $=0.001$ ). Penelitian ini menyatakan kualitas stimulasi yang baik menurunkan risiko terjadinya suspek gangguan perkembangan pada anak balita ${ }^{(8)}$

Stimulasi orangtua merupakan faktor psikososial dari perkembangan anak yang mempengaruhi perkembangan anak secara positif jika diberikan stimulasi secara teratur dan terarah serta sesuai dengan tingkat maturitas saraf anak sehingga anak akan lebih cepat berkembang dibandingkan dengan anak yang kurang/tidak mendapat stimulasi.Hal ini sejalan dengan penelitian yang dilakukan oleh Englund,dkk di Amerika Serikat tahun 2010 yang menyatakan bahwa keterlibatan orangtua dalam menstimulasi 
anak merupakan faktor prediktor pencapaian anak di masa depan ${ }^{(2)}$

Stimulasi sebaiknya dilakukan terhadap semua aspek perkembangan anak. Stimulasi sebaiknya dilakukan secara beragam seperti stimulasi audio visual, motorik, kognitif, emosisosial, dan moral-spiritual. Kualitas stimulasi yang baik diperhatikan dari kualitas interaksi anak dan orangtua dan dilakukan secara berulang dan dilakukan secara dini. ${ }^{(1)}$

Peran orangtua pada proses pembimbingan dan pengasuhan anak sangat besar, terutama dalam melawati masa penting dalam perkembangan anak (golden age). Hubungan yang baik antara orangtua dan anak sangat memfasilitasi perkembangan anak sedangkan hubungan yang kurang baik mengakibatkan anak mengalami kesulitan dalam perkembangannya. Hasil penelitian ini menunjukkan orangtua yang memberikan stimulasi dengan baik sebagian besar hasil penilaian perkembangan pada balita berada dalam kategori sesuai dengan tahap perkembangan yaitu $91,3 \%$ dan sisanya sebesar $8,7 \%$ dari anak yang mendapatkan stimulasi baik berada dalam kategori perkembangan tidak sesuai.

Hasil penelitian ini sejalan dengan penelitian yang dilakukan oleh Yusari di Lampung tahun 2011 yang mendapatkan hasil dari 34 anak yang mendapat stimulasi baik sebesar $91,2 \%$ anak berada pada perkembangan yang normal. Hasil tersebut menunjukkan adanya hubungan positif pemberian stimulasi baik dengan perkembangan anak yang berada dalam kategori sesuai tahap perkembangan (p value $=0,044)^{\cdot(17)}$

Pengetahuan mempengaruhi sikap dan tindakan orangtua dalam memberikan stimulasi yang akan berdampak pada perkembangan anaknya. Sehingga pada penelitian ini masih ditemukan orangtua yang kurang memberikan stimulasi dan perkembangan anak yang tidak sesuai karena kurangnya pengetahuan dan pengalaman dalam mengasuh anak. Semakin baik pemberian stimulasi maka perkembangan anakpun akan semakin baik. Untuk itu tenaga kesehatan perlu memberikan pendidikan kesehatan kepada orang tua terkait stimulasi pada tubuh kembang anak tertutama pada masa golden age.

\section{KESIMPULAN DAN SARAN}

Lebih dari separuh orangtua memberikan stimulasi perkembangan dengan baik dan lebih dari separuh perkembangan balita usia 12-36 bulan sesuai dengan usianya. Terdapat hubungan antara stimulasi orangtua dengan perkembangan balita usia 12-36 bulan. Diharapakan tenaga kesehatan dapat memberikan informasi kepada orangtua tentang cara memberikan stimulasi sesuai dengan usia anaknya dan melakukan deteksi dini perkembangan secara optimal.

\section{DAFTAR PUSTAKA}

1. Depkes RI. Pedoman Pelaksanaan Stimulasi, Deteksi dan Intervensi Dini Tumbuh Kembang Anak di Tingkat Pelayanan Kesehatan Dasar. Jakarta; 2012.

2. Soetjiningsih. Tumbuh Kembang Anak. 2nd ed. Jakarta: EGC; 2015.

3. IDAI. Mengenal Keterlambatan Perkembangan Umum [Internet]. IDAI. 2013. Available from: http://www.idai.or.id

4. Tjandrajani. Keluhan Utama pada Keterlambatan Perkembangan Umum di Klinik Khusus Tumbuh Kembang RSAB Harapan Kita. Sari Pediatr. 2012;13(6):373-7.

5. UNICEF. Early Childhood Development. 2002.

6. Dodik;Tin. Peran Stimulasi Orang Tua terhadap Perkembangan Balita pada Keluarga Miskin. J Penelit Kesehat Suara Forikes. 2008;1(1).

7. Dwi S Cahyaningsih. Pertumbuhan dan Perkembangan Anak dan Remaja. Jakarta: Trans Info Media; 2011.

8. Wulandari. Kualitas Stimulasi Orang Tua dan Perkembangan Anak Gemuk Usia 2-5 Tahun. J Midwifery Reprod. 2017;1(1).

9. Pawestri D. Pengaruh Pemberian Stimulasi dengan Acuan Buku KIA oleh Ibu terhadap Perkembangan Anak Usia 0-3 tahun di Posyandu Wilayah Kerja Puskesmas Raci Kabupaten Pasuruan. UNAIR: Tesis; 2015. Universitas Airlangga; 2015.

10. Sukamti. Stimulasi Dini pada Pola Asuh Berdampak Positif terhadap Perkembangan Anak Bawah Dua Tahun. J Ilmu dan Teknol Kesehat. 2014;2(1):27-35.

11. Brady . The Effects of Early Neglect on Cognitive, Language, and Behavioral Functioning in Childhood. Psychology. 2013;3(2).

12. Banhae. YK. Pengaruh Pemberian Stimulasi oleh Ibu terhadap Perkembangan Anak Usia 03 Tahun dengan Acuan SDIDTK di Posyandu Wilayah Kerja Puskesmas Oebobo Kota Kupang. 2015.

13. IDAI. Pentingnya Memantau Pertumbuhan dan Perkembangan Anak. 2016.

14. Nursalam. Asuhan Keperawatan Bayi dan 
Anak Untuk Perawat dan Bidan. Jakarta: Salemba Medika; 2008.

15. Padang DKK. Cakupan DDTK Kontak I dan Kontak IV Anak Balita Per Puskesmas Tahun 2016. Padang; 2017.

16. ANdalas P. Laporan Tahunan Puskesmas Andalas Tahun 2016. 2017. Padang; 2017.

17. Asih Y. Hubungan Pemberian Stimulasi Ibu dengan Perkembangan Balita di Posyandu. J Keperawatan. 2015;11(2).

18. Gunawan. Hubungan Status Gizi dengan Perkembangan Anak Usia 1-2 Tahun. Sari Pediatr. 2011;13(2). 

